\title{
The Political Economy of Township Government Debt, Township Enterprises and Rural Financial Institutions in China*
}

\section{Lynette Ong}

\begin{abstract}
This article sheds light on the ways in which township governments mobilized resources from local financial institutions, and how failure to repay many of these loans gave rise to sizeable local government debt. Mobilization of resources was done through loans to collective enterprises whose de facto owners were township authorities. Though the enterprises were nominal borrowers, loan transactions would not have occurred without guarantees by township governments. Another way of financial resource mobilization was by establishing local informal financial organizations that were subject to less strict regulations, and over which township authorities could exercise control. Further, because the enterprises' profits and taxes ultimately went to township authorities, and the enterprises also contributed towards provision of public goods that were the authorities' obligation, enterprise financing became a roundabout way in which township authorities sought financial assistance for their fiscal needs.
\end{abstract}

The Chinese media have recently talked about a looming local government debt crisis. ${ }^{1}$ Local government debt in China is a poorly understood concept, both in terms of its origins or causes and its magnitude. The only Western literature that has touched on the topic does so through the prism of inadequate public service provisions in poor rural areas owing to fiscal stress. ${ }^{2}$ There has been no study to date on how the debt comes about. ${ }^{3}$ A better understanding of the causes of debt is paramount since the law prohibits local governments from running fiscal deficits or engaging in debt financing. An appreciation of the various means by which local governments can

* The author is grateful for the comments provided by Jonathan Unger and Andrew MacIntyre; and has benefited from discussions with Shukai Zhao. All remaining errors remain the responsibility of the author.

1. See, for instance, "Local gov't debts sound warning," China Business Weekly, 25 April 2004 (available at http://www.chinadaily.com.cn/english/doc/2004-04/25/ content_326118.htm); and "Govt owes building companies 90b yuan," Xinhua, 28 October 2003 (available at http://www.chinadaily.com.cn/en/doc/2003-10/28/content_276044.htm).

2. See Christine Wong (ed.), "Financing local government in the People's Republic of China" (Hong Kong: Oxford University Press for the Asian Development Bank, 1997); and World Bank, "China: national development and sub-national finance - a review of provincial expenditures" (Beijing: Poverty Reduction and Economic Management Unit, East Asia and Pacific Region, 2002).

3. One possible exception is a Chinese language paper by S. Zhao, "Xiangzhen zhaiwu zhilei - 10 sheng (qu) 20 xiangzhen de diaocha" ("Burdens of township government debts - a survey of 20 townships in ten provinces (districts)"), unpublished manuscript, 2004. A slightly different version of the article by the same author, "Kunju zhong de xiangzhen caizheng" ("Township finance in great difficulties") has appeared in Zhongguo jingji shibao (China Economic Times), 6 September 2004.

(c) The China Quarterly, 2006 doi: 10.1017/S0305741006000063 
channel resources to serve their fiscal needs has important implications for a basic understanding of China's rural political economy.

This article focuses on one aspect of local government debt, that of township governments. It sheds light on the ways in which township governments mobilized resources from local financial institutions, and how failure to repay many of these loans gave rise to sizeable debt. Mobilization of resources was done through loans to collective enterprises whose de facto owners were township authorities. Though the enterprises were the nominal borrowers, loan transactions would not have occurred without guarantees by township governments. Another way of financial resource mobilization was by establishing local informal financial organizations that were subject to less strict regulations, and over which township authorities could exercise control. The corporate governance structure of these co-operative financial organizations is examined at length in this article to explain how and why strong interference by grassroots authorities took place. Furthermore, because the enterprises' profits and taxes ultimately went to township authorities, and the enterprises also contributed towards provision of public goods that were the obligation of the authorities, enterprise financing became a roundabout way in which township authorities sought financial assistance for their fiscal needs.

Empirical evidence for this study was collected in Sichuan province in mid-2004 through in-depth interviews with managers and employees of rural financial institutions, and township, county and provincial officials who deal or have dealt with collective enterprise management, government finance and financial institutions. Detailed case studies were conducted in four townships in the province.

The article begins by summarizing the different types of local government debt, before addressing the causes of debt and providing estimates of its magnitude. It then analyses the corporate governance structures of the Rural Co-operative Foundations and the Rural Credit Co-operatives as observed in the case studies, and examines the implications for local government interference in financial resource allocations. Finally, the article presents empirical evidence consisting of a combination of primary and secondary data.

\section{Budget Law and Categories of Local Government Debt}

Regulation 20 of China's Budget Law (yusuanfa 预算法) specifies that local governments - the provincial, prefectural, county and township governments - should abide by the principle of balancing revenue and expenditures, and are not to run fiscal deficits. Regulation 28 stipulates that there should be no local government debt financing of any form, including issuance of local government bonds and public fund-raising. 4 Despite these formal restrictions,

4. S. Yang, Zhongguo difang caizheng fazhan yanjiu baogao: Zhongguo difang zhengfu huoyou zhaiwu wenti yanjiu (Research Report on the Developments of China's Local Government Finance) (Beijing: Zhongguo caizheng jingji chubanshe, 2003), p. 4. 
local governments have been accumulating debt as a result of financing.

This debt can be classified into five major categories. ${ }^{5}$ The first is direct borrowing or debt financing, including borrowing from the Central Ministry of Finance, earmarked on-lending (zhuan xiang zaidaikuan 专项再贷款) from the Central Bank (the People's Bank of China), and loans from foreign governments and international financial institutions. The second category consists of arrears and goods bought on credit (guazhang 挂账), including wage arrears of school teachers and local administrative unit (xingzheng danwei 行政 单位) officials, and credit loans of state grain companies. The third is borrowing by the local governments' functional departments or subsidiaries of the departments, usually channelled through local nonbanking financial institutions or local commercial banks for use in public services and infrastructure. The fourth is loans guaranteed by local governments: local authorities have often acted as guarantors for local enterprises and other organizations, despite the prohibition by the Guarantee Law (danbaofa 担保法) for them to provide guarantees to any organization or individual except for borrowing from foreign or international donor agencies. The final category is debts of local informal financial institutions and local state-owned enterprises, including financial losses and non-performing assets of rural cooperative foundations and local trust investment companies.

\section{Causes of Local Government Debt and Estimates of its Magnitude}

Impacts of fiscal reforms on township governments' fiscal situation. The township fiscal system was established in 1983 based on the principle that "each level of government has its own budget." The national fiscal system has undergone various reforms since the 1980s, including the fiscal contracting system in 1988, the tax sharing system in 1994 and the tax-for-fees policy in 1998, which have left local governments financially worse off than before. As a World Bank report ${ }^{6}$ notes: "Over the past two decades there has been a considerable devolution of expenditures to local governments, which are responsible for day-to-day government administration and the provision of social services while at the same time the tax sharing system has re-centralized revenue assignments. These two policy thrusts have created vertical fiscal gaps, which have not been offset by inter-governmental transfers." The recent reforms of the rural tax system that abolished the collection of various fees from rural

5. N. Wang, Difang caizheng gaige yanjiu (Research on Local Public Finance Reforms) (Chengdu: Xinan caijing daxue chubanshe, 2003), p. 175.

6. World Bank, "National development and sub-national finance - a review of provincial expenditures" (Beijing: Poverty Reduction and Economic Management Unit, East Asia and Pacific Region, World Bank, 2002). 
residents further strained the township governments' financial situation. Against the backdrop of falling revenue is an inadequate intergovernmental transfer system. All these factors contribute to the financial stress experienced by the township governments, and their resorting to various means to raise revenue.

The tax sharing system (fenshuizhi 分税制) implemented in 1994 was aimed at increasing the central authority's share of revenues to enable it to exert greater autonomy in redistributing revenue across regions. The central government had regained revenue responsibility over major taxes, such as the value-added tax and income tax, while leaving expenditure responsibilities largely unchanged. As a consequence, the central share of tax revenue jumped from 22 per cent in 1993 to 55.7 per cent in the following year, ${ }^{7}$ while the local governments' share of tax revenue fell from an average of 70.2 per cent to around 48 per cent. ${ }^{8}$ The mismatch of revenue and expenditure responsibilities is particularly stark at the county and township levels, which are responsible for providing the bulk of public services such as basic education and healthcare. ${ }^{9}$ The resultant fiscal gap has not been aided by the inter-governmental transfer system that was originally envisaged to compensate local governments for the loss of tax receipts: the tax rebate formula has no clear rules on how it should be calculated, and the transitional equalization transfers remain grossly underfunded. ${ }^{10}$

Lack of budgetary revenue has resulted in local governments relying heavily on extra-budgetary funds to finance their operations. Various arbitrary fees, commonly known as tongchou (统筹) and tiliu (提留) or santi wutong (三提五统), were prominent in township governments' extra-budgetary funds before the implementation of a national policy to convert fees into taxes in 1998. The abolition of fees, aimed at reducing financial burdens on farmers, has significantly shrunk the grassroots authorities' coffers, leaving them with few revenue sources. Fiscal situations of township governments are expected to deteriorate further with the phasing-out of agricultural tax by $2009 .{ }^{11}$

Borrowing to finance township enterprises. This article focuses on the township government - the lowest formal level of government in China - and the collective enterprises managed by them, more commonly known as township enterprises. In practice, township officials are the managers and de facto owners of the collective

7. Ibid.

8. "Zhongyang he difang de caizheng boyi" ("Conflicts between the central and local government finance"), Caijingjie, 5 April 2004. Available at http://finance.sina. com.cn.

9. World Bank, "National development and sub-national finance."

10. Ibid.

11. As part of the central government's effort to improve the living standard of the rural residents, Premier Wen Jiabao announced in March 2004 that agricultural tax is to be phased out in five years. 
enterprises since the real owners - the collectives, that is the community - have little say over how the enterprises are run and managed. On the other hand, the firms that the other levels of local governments run are state-owned enterprises rather than collective enterprises. $^{12}$ A key difference between them is the way in which profits and taxes from the enterprises are distributed. The 1980s fiscal decentralization policies created incentives for township governments to develop collective enterprises since tax revenue collected from them does not have to be shared with higher-level authorities. Consequently, until the mid-1990s, local governments were actively involved in the financing of these enterprises.

Other causes of local government debt. A Chinese-language study on the debt situations of 20 townships in various provinces in 2004 suggests that the main reasons for debt financing for those townships were: the compulsory nine-year education scheme; debt owed by the Rural Co-operative Foundations; construction of basic infrastructure and facilities; wage arrears and debt owed to individuals; township enterprise financing; daily expenditures; interest expense from previous loans; and fulfilment of tax quota required by higher level authorities. ${ }^{13}$ In addition, contributing factors to the debt problem may be the existence of corruption, local officials' misconduct and plundering of public resources.

Estimates of local government debt. There are various estimates of local government debt, and all point to sizeable financial liabilities. A nationwide inspection conducted by the ministry of finance in 2001 revealed that the township and village levels' combined debt was about 370 billion yuan (US $\$ 44.7$ billion). ${ }^{14}$ A more recent study suggests that total debt at village level is 370 billion yuan, at township level 215 billion yuan and at county level 410 billion yuan, which give a combined local government debt level of one trillion yuan, or 8.3 per cent of China's total GDP at 2003 prices. In other words, the debt burden of an average village is 500,000 yuan, an average township is five million yuan and an average county is 150 million yuan. ${ }^{15}$

What is more staggering is the fact that these are only "preliminary estimates," since the actual size of local government debt is largely unknown because of the overwhelming proportion of contingent

12. For further explanations of the differences between state-owned and collective enterprises, see Qian, "Reforming corporate governance and finance in China," in Masahiko Aoki and Hyung-Ki Kim (eds.), Corporate Governance in Transition Economies: Insider Control and the Role of Banks (Washington DC: The World Bank Press, 1995), pp. 215-252.

13. Zhao, "Burdens of township government debts."

14. "Zhaiwu de kunrao - difang zhengfu zhaiwu wenti" ("Bothered by debt - debt problems of local governments), CaijingJie, 5 April 2004. Available at http://finance. sina.com.

15. Tian Fa and Chenying Zhou, "Chongguo difang zhengfu jian caizheng guanxi" ("Reconstruct financial relations among local governments"), Gaige (Reform), No. 2 (2004). 
liabilities (yinxing zhaiwu 隐性债务). ${ }^{16}$ For instance, official estimates of the debt level often do not include the financial liabilities of stateowned or township enterprises under the local governments' control, though they are the ultimate debtors if these enterprises fail to repay.

This article focuses on two important ways in which township governments mobilized resources from the financial system. First, the township governments, through their de facto ownership of collective enterprises, arranged for their enterprises to receive financing from banks and non-banking financial institutions. On the books of the financial institutions, the loans were provided to the collective enterprises; however, many of these transactions would not have occurred without the township governments acting as the guarantors. ${ }^{17}$ This suggests that the township governments bear the final responsibility in the event of loan defaults by the collective enterprises. Furthermore, because these enterprises contributed profits and taxes to the township governments, and fulfilled the social obligations imposed on them by the township authorities, such as providing funds towards construction of roads and schools in the communities, they became a conduit through which township authorities could indirectly raise funds to finance their budgetary expenditures. Evidence provided in this study suggests that financing township enterprises accounts for a significant proportion of township government debt an area often overlooked by the existing literature.

Secondly, the township authorities had gained access to funds by establishing local informal financial organizations, such as the Rural Co-operative Foundations, that amassed savings from local residents. Because these were informal financial organizations and were subject to less strict regulatory control and supervision, the township authorities could directly borrow money from them.

\section{Rural Co-operative Foundations and Rural Credit Co-operatives}

This section examines two key rural financial institutions in China, one informal and one formal. They were subject to different regulatory requirements and hence there were different implications for their lending to local governments. The research used primary

16. Jia Kang, director of the Institute of Finance under the Ministry of Finance, commented that the reality of the debt problem might be more serious that the figures suggest, as "recorded debts are only part of local governments' liabilities. Their liabilities also include unpaid construction bills for infrastructure, guarantees for loans and some corrupt officials' personal debts." "Local government debts sound warning," China Business Weekly, 25 April 2004.

17. This is a finding from my interviews with bank and rural credit co-operative officials. It is also confirmed by Che and Qian, "Without the community government's involvement, it is usually very difficult, if not impossible, for Township and Village Enterprises to obtain loans directly from either the Agricultural Bank of China or Rural Credit Cooperatives" (p. 6) "Institutional environment, community government, and corporate governance: understanding China's township-village enterprises," Journal of Law, Economics and Organization, Vol. 14, No. 1 (1998), pp. 1-14 
data collected from interviews and field research in Sichuan, and secondary data from Chinese-language literature.

\section{Rural Co-operative Foundations. The Rural Co-operative} Foundations (RCFs) (nongcun hezuo jijinhui 农村合作基金会) were informal financial institutions established by local authorities in the mid-1980s, subsequently shut down by the central government in the late 1990s. They were "informal" because they were not officially regulated or sanctioned by the Central Bank, though their development was approved and encouraged by the central government at various points. $^{18}$

Most RCFs were established by the township and village economic organizations (xiangcun jiti jingji zuzhi 乡村集体经济组织), which were effectively under the control of the township governments and village cadres, for the purpose of amassing collective funds and households' savings and channelling them into income-generating activities. ${ }^{19}$ The other - more official - goal of establishing RCFs was to stem the outflow of financial resources from rural areas, since only modest funds were circulated back to the rural sector through the formal credit system.

The RCFs' start-up capital mainly came from the collective funds (jiti zijin 集体资金) of the township and village organizations. ${ }^{20}$ However their subsequent growth was stimulated by capital contributions by rural households. Since the RCFs were not regulated by the Central Bank they were able to offer higher interest rates to depositors, and this contributed significantly to their success in drawing a large pool of rural savings. Their ability to attract farmers' contributions was aided by the perception that they were governmentbacked financial organizations, and hence their deposits carried an implicit government guarantee. ${ }^{21}$ In the late 1990s, the RCFs became the single largest informal financial organizations in the country, with deposits reaching more than 100 billion yuan in 1996, compared to 800 billion yuan in the official and more established Rural Credit Cooperatives. $^{22}$

The RCFs were managed by the agricultural economic management stations at the township level. Since these stations came under the direct control of the township governments, the latter had

18. T. Wen, Nongcun hezhou jijinghui de xingshuai: 1984-1999 (The Rise and Fall of the Rural Co-operative Foundations: 1984-1999) (2000). Available at http://forum50. cei.gov.cn/newwork/cyfx_wtj_20010060704.htm.

19. Of course not all the funds were invested in income-generating activities, some had gone into the pockets of township and village officials, which was a major reason leading to their eventual closure. Ibid.

20. Guo Xiaoming and Lei Xioming, Rural China Entering the 21st Century: Credit, (2000). Available at http://www.usc.cuhk.edu.hk/wk_wzdetails.asp?id=1606.

21. Cheng Enjiang, Christopher Findlay and Andrew Watson. "Institutional innovation without regulation: the collapse of rural credit foundations and lessons for further financial reforms." in Findlay, Watson, Cheng and Zhu (eds.), Rural Financial Markets in China (Canberra: Asia-Pacific Press, 2003). 
enormous influence over allocations of RCF resources. At 1998 yearend, audits of a county's RCFs in Hebei province revealed that loans to township and village enterprises accounted for 38 per cent of the total equity, and over 90 per cent of the loans were a result of township governments' directives and most were non-recoverable. ${ }^{23} \mathrm{~A}$ portion of the RCFs' funds was also directed by township authorities to finance public infrastructure, such as road-building, and construction of schools and hospitals. Some local governments even went to the extent of directing funds from the RCFs to make up for the shortfalls in their fiscal budgets. ${ }^{24}$

In the late 1990s, some RCFs in Sichuan and Hebei experienced the "bank runs" phenomenon: they failed to honour withdrawals by some depositors. In some locales, "bank runs" grew to such a scale that they posed a threat to social and political stability, and the credibility of the central government was at stake. ${ }^{25}$ Finally, the State Council ordered the closure of RCFs nationwide in 1999. The closure was accompanied by a thorough auditing of RCFs' accounts, which revealed serious problems with non-performing loans and misuse of funds by the local governments. ${ }^{26}$

Rural Credit Co-operatives. The Rural Credit Co-operatives (RCCs) (nongcun xinyong hezuoshe 农村信用合作社) are only “co-operative" financial organizations in name. Historically, in their various forms of existence, the RCCs had been either de facto local governmentcontrolled financial organizations or extensions of the state banking system; though since the late 1990s the central government has introduced some reforms to build an internal chain of control within the organizations. There has always been pervasive influence by local officials over their credit allocations.

After the collectivization of agriculture in 1959, the RCCs were made subordinate arms of the communes (what are now the townships). The brigade used it as part of its budgetary system. ${ }^{27}$ Subsequently, with the collapse of the commune system in 1979, the central authority made the RCCs subordinate to the Agricultural Bank of China (ABC). The RCCs functioned as branches of the state bank at the grassroots level, and they were managed simply as an extension of the bank bureaucracy. ${ }^{28}$

In an attempt to restructure the formal rural financial system, the central government separated the RCCs from the ABC in 1996. In

23. Wen, The Rise and Fall of the Rural Co-operative Foundations.

24. Guo and Lei, Rural China Entering the 21st Century.

25. Wen, The Rise and Fall of the Rural Co-operative Foundations.

26. Cheng et al., "Institutional innovation without regulation."

27. The Chinese word caizheng is usually translated as "fiscal" or "finance" in English. However, I have used the term "budgetary system" here to differentiate it from the fiscal system that collects tax revenues, and the financial system that mobilizes and channels financial resources.

28. On Kit Tam, "Rural finance in China," The China Quarterly, No. 113 (1988), pp. $60-76$. 
1997, the central government established RCC unions at the county level to assume the role of managing (guanli 管理) township RCCs. Township or grassroots RCCs are independent legal entities, responsible for their own profits and losses (zifu yinkui 自负盈亏); but are managed by the county RCC unions in terms of staff appointments, personnel management and training. Grassroots RCCs are also required to obtain approval for major loan decisions from the county unions. ${ }^{29}$ Since 2000 , the central government has experimented with a series of reforms to introduce various property rights models to the RCCs. ${ }^{30}$

Corporate governance structures of the RCFs and RCCs. The corporate governance structures of the RCFs and RCCs have important implications on the township governments' influence on loan allocation decisions. Though the RCFs and RCCs adopt the corporate governance structure of co-operative organizations, as depicted in Figure 1, in practice the members' representative meetings are often made up of township and village cadres, instead of the farmers who have paid to become members (rugu huiyuan 入股会员). From interviews with more than 200 RCC member households, less than 5 per cent have ever attended a members' representative meeting. Those who have are village or township cadres, such as village heads, village Party secretaries and township officials. As a result, the members' representative meeting - the highest governing body - often becomes a rubber stamp; the real authority lies with the head of the board of directors (lishizhang 理事长).

In the case of the RCFs, the board of directors was led by the township head, township finance bureau director or someone appointed by the township government. ${ }^{31}$ The board of directors of the RCC is headed by the RCC manager, and board members consist of RCC staff members. ${ }^{32}$ The boards of supervisors of the RCFs and RCCs are led by the township Party secretaries, and the board members consist of township cadres. ${ }^{33}$ This suggests a fundamental lack of separation of power among the different bodies, and ineffective realization of the functions each of them is supposed to

29. In the two counties where fieldwork was conducted, township RCC managers have the right to disburse loan amounts below 20,000 yuan. Any loans above 20,000 yuan have to be referred to the county RCC unions.

30. In 2000, pilot reforms to turn existing credit co-operatives into rural commercial banks were carried out in Jiangsu province. By early 2003, all township RCCs in Jiangsu had been merged into RCC county unions, and the provincial RCC federation had been established. In August 2003, the central authority carried out experimental reforms of the RCCs in eight provinces where the management control rights of RCCs were handed to the provincial governments.

31. Personal interview with the Sichuan Ministry of Agriculture, which was the base of the former Sichuan Rural Co-operative Management Station; and some township officials.

32. Personal interview with RCC managers.

33. Personal interview with RCC managers; the Sichuan Ministry of Agriculture, which was the base of the former Sichuan Rural Co-operative Management Station; and some township officials. 
Figure 1: Corporate Governance Structure of Co-operative Financial Organizations

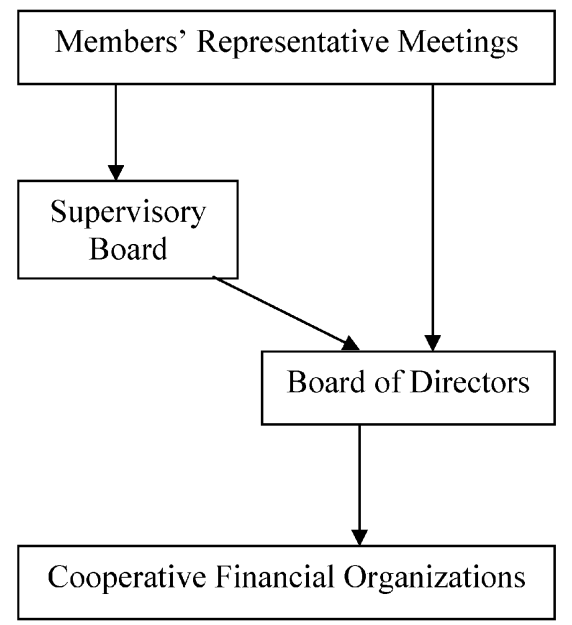

perform. This results in an absence of checks-and-balances on the authorities of the managers and directors, who wield enormous power in deciding how financial resources are utilized.

Consequences of inadequate corporate governance structures. The closeness between township administrations and the management of the co-operative financial establishments meant that the local financial organizations often become a form of township government coffer (xiaojinku), since those who manage the financial resources are the people who run the township governments. It reflects a fundamental entanglement in the Chinese system between Western notions of "finance" (jinrong 金融) and "public finance" (caizheng 财 政). The cadres in charge of public finance at the local level are also the decision makers for the financial organizations. This is more so in the case of the RCFs than the RCCs, since the former were subjected to less regulation and supervision than the latter.

A key feature of the RCFs was that local governments could borrow directly from them whereas they were not able to do so from the RCCs. As local informal financial organizations, the RCFs gave the local authorities better access to resources than the RCCs which were subjected to stricter regulatory controls and supervision. Direct loans to government and government-related departments accounted for nearly 20 per cent of total loans in Sichuan's RCFs, as indicated in Table 1.

The RCFs were primarily township-based financial organizations: over 90 per cent of all RCFs in Sichuan were located at the township level. ${ }^{34}$ Among the different levels of government, the township

34. There were 4,435 RCFs in Sichuan, according to the statistics from the Sichuan Ministry of Agriculture, which was the base of the former Sichuan Co-operative Management Station. Of these, 4,251 or $95.9 \%$ were located at townships. 


\section{Table 1: Sichuan RCFs' Consolidated Accounts Before Deposits Honouring (as of 16 March 1999)}

\begin{tabular}{lcc} 
Total assets (million yuan) & $31,620.0$ & \\
Total loans/credit (million yuan) & $21,460.0$ & $\%$ \\
of which: & & \\
Households & $7,960.0$ & 37.1 \\
Enterprises & $6,760.0$ & 31.5 \\
Government and government-related units & $3,850.0$ & 17.9 \\
$\quad$ Village collectives and agriculture service & $2,890.0$ & 13.5 \\
organizations & & \\
of which: & & \\
$\quad \begin{array}{l}\text { Non-performing loans } \\
\text { Performing loans }\end{array}$ & $10,840.0$ & 50.5 \\
& $10,620.0$ & 49.5 \\
\hline $\begin{array}{l}\text { Total deposit/liabilities (million yuan) } \\
\text { of which: }\end{array}$ & $30,680.0$ & $\%$ \\
$\quad$ Individuals & & \\
$\quad$ (Members' shares) & $25,690.0$ & 83.7 \\
$\quad$ Village collectives and agriculture service & $(21,560.0)$ & $(70.3)$ \\
$\quad$ organizations & $4,130.0$ & 13.5 \\
\end{tabular}

Note:

The consolidated accounts are as provided to the author by the source. Readers may notice that total loans are only two-thirds of total assets. The other one-third of assets is unaccountable for, which further illustrates the inadequate management and nontransparent nature of the organizations.

Source:

Sichuan Ministry of Agriculture (the base of the former Sichuan Rural Co-operative Management Station)

authorities had the greatest access to the funds: loans to township enterprises accounted for 35.6 per cent of the total, as indicated in Table 2. Combining that with "governments' loans," which were those provided directly to the township governments, the RCFs' lending to the township authorities in Sichuan constituted no less than half of all their loan portfolios.

By offering returns higher than other rural financial organizations, the RCFs were able to attract members, and that helped to mobilize a large pool of savings from farmers and the collectives. The consolidation of all RCF accounts in Sichuan province immediately following the closures shows that they had absorbed 30.7 billion yuan of deposits, of which households' savings (or members' shares) were 21.6 billion yuan or 70 per cent of the total. Deposits by village collectives and agricultural service organizations totalled 4.1 billion yuan or 13.5 per cent. When the RCFs were shut down by the central government in March 1999, only households' savings were honoured since the central government's priority was to thwart any outburst of rural unrest. Deposits by collectives, such as production teams, were 


\section{Table 2: Sichuan RCFs' Consolidated Accounts After Deposits Honouring (as of 31 December 1999)}

\begin{tabular}{lrc}
\hline Net fixed assets (million yuan) & 551.0 & \\
Total credit/loans (million yuan) & $9,584.7$ & \\
$\quad$ of which: & $3,416.8$ & 35.6 \\
Township enterprises' loans & $2,611.0$ & 27.2 \\
Households' loans & $1,255.9$ & 13.1 \\
Governments' loans & $1,152.3$ & 12.0 \\
Other departments' loans & 343.9 & 3.6 \\
$\quad$ Education departments' loans & 322.8 & 3.4 \\
Village groups collectives' loans & 269.8 & 2.8 \\
Agricultural organizations' loans & 99.1 & 1.0 \\
$\quad$ Transport departments' loans & 18.3 & 0.2 \\
$\quad$ Health departments' loans & $6,878.9$ & 71.8 \\
Total government-related loans & & \\
\hline & $16,128.8$ & $\%$ \\
\hline Total debt/liabilities (million yuan) & $5,520.9$ & 34.2 \\
Members' shares (individual) & $5,500.0$ & 34.1 \\
Borrowings from central government & $1,652.5$ & 10.2 \\
Borrowings from provincial ministry of finance & 863.5 & 5.4 \\
Borrowings from work units and individuals & 848.8 & 5.3 \\
Borrowings from extrabudgetary funds (yusuanwai zijin) & 780.0 & 4.8 \\
Members' shares (collective) & 506.2 & 3.1 \\
Commissioned funds (collective) & 286.3 & 1.8 \\
Loans from financial organizations & 170.5 & 1.1 \\
Commissioned funds (individual) (daiguan zijin) & & \\
\hline & $1,191.1$ & $\%$ \\
\hline Total recovered loans (million yuan) & 651.9 & 54.7 \\
Households & 233.8 & 19.6 \\
Township and village enterprises & 137.2 & 11.5 \\
Governments & 49.2 & 4.1 \\
Education departments & 43.6 & 3.7 \\
Agricultural organizations & 37.3 & 3.1 \\
Village group collectives & 29.5 & 2.5 \\
Transport departments & 5.2 & 0.4 \\
Cultural departments & 3.3 & 0.3 \\
Health departments & & \\
\hline & & \\
\hline
\end{tabular}

Source:

Sichuan Ministry of Agriculture (the base of the former Sichuan Rural Co-operative Management Station)

not honoured because of the RCFs' shortages of funds. ${ }^{35}$ Some of these deposits were transferred to the RCC branches in the respective localities. The RCCs had to guarantee the depositors a 
higher-than-market interest rate since the RCFs' rates had been higher. $^{36}$

A glance at the RCFs' consolidated accounts before deposit honouring (Table 1) suggests that they were in no position to honour all deposits, the implication of which was that the township governments had to take over their remaining liabilities. ${ }^{37}$ The amount of total deposits, 30.7 billion yuan, was roughly the size of the total asset value, inclusive of loans. Two-thirds of their assets were loans, and half of the loans, some 10.8 billion, were officially classified as non-performing. That meant that had the RCFs been able to recover all "performing loans," and all the non-loan assets could be liquidated, they would only be able to honour 80 per cent of individuals' deposits. This shows that honouring only individual depositors was not solely a political decision because of the "bank runs" phenomenon; it was also a decision born out of necessity.

A comparison of the composition of liabilities before and after deposit honouring (Tables 1 and 2) suggests that the RCFs had to borrow from various sources, including 5.5 billion yuan from the central government, 1.6 billion yuan from the provincial ministry of finance, 863 billion yuan from various work units and 849 billion yuan from the extrabudgetary funds, to pacify the discontent of individual savers. ${ }^{38}$ In spite of that, an outstanding 5.5 billion yuan of members' savings remained unhonoured as of 31 December 1999. The liabilities of the RCFs - borrowings from various sources and unhonoured members' shares - in turn became the debts of the township authorities in the localities of the RCF establishments.

\section{Case Studies}

The primary data were collected during field research in mid-2004, including interviews with the RCC managers, those who used to manage the RCFs, member households and grassroots officials. The four townships are located in two counties (in two different prefectures) in Sichuan. Sichuan was chosen partly because it was one of the provinces where the RCFs were most vibrant. When controversial statistical figures are involved, such as local government

36. In township $\mathrm{X} 1$ in county $\mathrm{X}$, for the total deposit of 5.2 million yuan, the RCC had to pay depositors about 90,000 yuan extra interest a year to compensate for the difference between the RCF's and the market interest rates between 1999 and 2003. Personal interview with RCC managers.

37. Document No. 3 (1999) issued by the State Council specifies: "The local governments are responsible for doing what they have to in order to protect the legal rights of farmer depositors, and to maintain social stability in the countryside." This implies that the central government had held the local authorities responsible for honouring all individual deposits and for any shortfalls that might arise.

38. When I was told of the various sources of funds, I probed to ask why these particular sources. The interviewee, who used to work at the former Sichuan Rural Co-operative Management Station, provided no direct answer. However, I was given the impression that at those times, the local authorities were in such dire straits that they had to borrow from whoever had surplus funds and were willing to lend. 
debt levels, I have tried to confirm the figures with more than one interviewee.

The four townships studied, randomly selected, ${ }^{39}$ offer four different economic conditions in rural China, though the latter two are somewhat similar. The two counties are situated in the south-west and north-east of the province; they face diverse natural conditions and engage in different economic activities. $\mathrm{X}$ county is better off in economic terms than Y county; $\mathrm{X}$ is also more industrialized, while $\mathrm{Y}$ is still primarily subsistent agricultural-based ${ }^{40}$; and $\mathrm{X}$ is relatively well endowed with minerals, including coal, sulphur iron, plaster stone, sandstone and granite, which gave rise to many enterprises engaged in mineral extraction and processing.

$\mathrm{X} 1$ township is the seat of $\mathrm{X}$ county and is more service-based than the other three. X2 township is quite rich in natural resources, and has the greatest number of township enterprises among the four. Y1 and $\mathrm{Y} 2$ townships in $\mathrm{Y}$ county are still largely agricultural. There were $\mathrm{RCF}$ branches in $\mathrm{X} 1, \mathrm{Y} 1$ and $\mathrm{Y} 2$.

Township enterprise financing and collapse of township enterprises. My field investigations suggest that loans to township enterprises were often given on the premise of the township governments acting as guarantors, without any physical collaterals. In instances where collaterals were present, the enterprise assets were grossly overvalued, so much so that in the events of non-repayment, the RCCs or RCFs could not recover the loan amount even if the assets were liquidated. ${ }^{41}$ Guarantees and collaterals aside, I was told by more than one RCC manager that before the mid-1990s they were under great political pressure to finance projects initiated by local officials, such as township enterprises and construction of government office buildings. The pressure to "support" the local authorities was particularly acute for the local financial organizations as compared to the grassroots branches of the state-owned banks, because while the latter had to report to their functional superiors at higher levels the former had no one to report to since they were independent legal entities responsible for their own profits and losses. ${ }^{42}$

The second half of 1990s saw the widespread collapse of township enterprises: in X county, 239 township enterprises in 1995 had been reduced to just 30 in 2003. Various reasons are given for the crumbling of township enterprises. As the head of X1 township aptly summed up: "Many collective enterprises were developed out of a

39. The townships were assigned by the relevant local hosts. I was not aware of any particular reasons why they were selected, though I did express to the hosts an interest in researching localities with dissimilar economic conditions.

40. In X county, secondary sector accounts for $55 \%$ of its GDP, and agriculture $21 \%$. In Y county, agriculture accounts for more than half its GDP, and industry $13 \%$.

41. Personal interviews with RCCs' managers and those who used to manage the RCFs.

42. The headquarters of the state-owned Agricultural Bank of China (ABC) in Beijing is a legal entity responsible for the profits and losses of all $\mathrm{ABC}$ branches nationwide. Bank officers in the township branches are accountable to those in the 
'me-too' mentality and ready access to financial capital. There was no viable business model to start with; no due diligence was conducted to ensure market demand for the products existed; and many township governments simply set up enterprises and built more factories because their counterparts in the next township were doing so." Furthermore: "It was easy for local governments to borrow loans from local financial organizations particularly the RCFs and the RCCs since the local governments had close relationships with those who ran these organizations."

As a result of flawed business models and bad management, when the supply of capital dried up following the collapse of the RCFs and the tightening of loan provisions by the central government during the mid and late 1990s, many township enterprises simply collapsed overnight, and only a handful that were in better shape were transformed into private enterprises.

In $\mathrm{Y}$ county, similar reasons were given to account for the widespread collapse, though mismanagement of enterprise resources seemed to be more severe here. Residents in Y1 and Y2 townships spoke of "silk factories that produced silk garments of inferior quality"; and "factories set up in remote places that were highly expensive to transport raw materials to and from and when finished products were sent to end markets." In addition, some revealed that even "those collective enterprises that produced good products could not sustain because the local government officials managing them simply plundered from them - treating themselves to banquets after banquets, and buying Santana using the enterprises' resources."

Township governments' fiscal positions. This section contrasts the fiscal positions of the two townships in X county, as shown in Tables 4 and $5 .^{43}$ Since revenue accounted for only 28 per cent of expenditures in 2003, X2 township was unable to fund all the budgetary expenditures itself if relying on its budgetary revenue. Even after discounting two major expense items that were paid for by the county government - education, and healthcare and medical expenditure $^{44}$ - the revenue of X2 township government was still insufficient to pay for the township officials' salaries (classified under "administrative and management fees") and other expenditures

footnote continued

counties, provinces and the headquarters. On the other hand, the township RCCs and $\mathrm{RCFs}$ were all independent legal entities. Personal interviews with managers from the $\mathrm{ABC}$ and the RCC.

43. Tables 4 and 5 are summaries of the financial statements in the two townships. While I have full details of the fiscal data, I have made commitments to protect the identities of the interviewees and those of the townships. Similar data are not available for the townships in $\mathrm{Y}$ county.

44. After widespread nationwide wage arrears of teachers' salaries, since 2001 the county governments have been held financially responsible for the teachers' salaries by a central government policy. County governments have also been made responsible for salaries of medical workers since 2003 . 
Table 3: Basic Indicators of Four Studied Townships (2003)

\begin{tabular}{|c|c|c|c|c|}
\hline \multirow[b]{2}{*}{ Townships } & \multicolumn{2}{|c|}{ County $X$} & \multicolumn{2}{|c|}{ County $Y$} \\
\hline & $\mathrm{X} 1$ & $\mathrm{X} 2$ & Y1 & $\mathrm{Y} 2$ \\
\hline Of the total population: & & & & \\
\hline Agricultural population (\%) & 35.8 & 97.2 & 95.2 & 96.2 \\
\hline Non-agricultural population (\%) & 65.6 & 2.8 & 4.8 & 3.8 \\
\hline $\begin{array}{l}\text { Domestic production value } \\
\text { (million yuan) }\end{array}$ & 265.4 & 279.4 & 21.78 & 28.88 \\
\hline \multicolumn{5}{|l|}{ Of which: } \\
\hline Primary $(\%)$ & 25.4 & 8.9 & - & - \\
\hline Secondary $(\%)$ & 29.8 & 96.4 & - & - \\
\hline Tertiary $(\%)$ & 44.8 & 0.0 & - & - \\
\hline Gross per capita income (yuan) & 2,211 & 2,667 & 1,820 & 1,886 \\
\hline Total revenue (million yuan) & 1.23 & 1.01 & 1.86 & 2.05 \\
\hline $\begin{array}{l}\text { Officially reported debt (million } \\
\text { yuan) }\end{array}$ & - & - & 3.28 & 12.1 \\
\hline $\begin{array}{l}\text { Total savings in financial } \\
\text { organizations (million yuan) }\end{array}$ & 25.00 & 6.83 & - & - \\
\hline
\end{tabular}

Source:

Yearbooks of $\mathrm{X}$ and $\mathrm{Y}$ counties

without a subsidy from the county government. The functioning of the township authority was largely reliant on financial assistance from higher levels of governments.

By contrast X1 township, being a county seat, hosts a large number of individual commercial establishments (geti gongshanghu 个体工商 户) that produce individual income tax accounting for 18 per cent of the tax revenue. Nevertheless, X1's functioning depended almost entirely on transfers, especially as the previous year's fiscal deficits were about half of the current year's total tax revenue.

The composition of X2 township's fiscal income in $1995,{ }^{45}$ as shown in Table 6, points to some interesting observations about the impact of the tax-for-fees (feigaishui 费改税) reform and township enterprise transformation on the township's fiscal situations. In 1995, definitions of the categories of fiscal income were different: budgetary funds were transfers from the county government; extra-budgetary funds consisted of various fees and surcharges, including education surcharges and broadcasting fees or santi wutong (三提五统); and self-raised funds were mostly profits of township enterprises. ${ }^{46}$ It is

45. I have made several attempts to obtain similar data for the other three townships, but these data from a decade ago were only available from X2 township. 46. The definitions of the various fiscal funds were provided by the township finance bureau director. 
Table 4: X1 Township Budgetary Revenue and Expenditures (2003)

\begin{tabular}{|c|c|c|c|}
\hline & Yuan & & Yuan \\
\hline $\begin{array}{l}\text { Total tax revenue } \\
\text { of which: }\end{array}$ & $402,522.5$ & $\begin{array}{l}\text { Total expenditures } \\
\text { of which: }\end{array}$ & $1,323,790.0$ \\
\hline Business tax $(62.6 \%)$ & $251,966.6$ & $\begin{array}{l}\text { Education expenses } \\
\quad(46.2 \%)\end{array}$ & $611,226.8$ \\
\hline $\begin{array}{l}\text { Individual income tax } \\
(18.2 \%)\end{array}$ & $73,326.0$ & $\begin{array}{l}\text { Admin and } \\
\text { management fees } \\
(25.5 \%)\end{array}$ & $336,982.0$ \\
\hline Agricultural tax $(16.9 \%)$ & $67,955.5$ & $\begin{array}{l}\text { Healthcare expenses } \\
\qquad(9.8 \%)\end{array}$ & $129,247.0$ \\
\hline $\begin{array}{l}\text { Intergovernmental } \\
\text { transfer }\end{array}$ & $1,035,397$ & & \\
\hline Previous year revenue & $(210,428.4)$ & End-of-year balance & $(96,298.9)^{*}$ \\
\hline Budgetary revenue & $416,113.6$ & $\begin{array}{l}\text { Budgetary } \\
\text { expenditures }\end{array}$ & $1,350,972.8$ \\
\hline Extrabudgetary revenue & $258,835.1$ & $\begin{array}{c}\text { Extrabudgetary } \\
\text { expenditures }\end{array}$ & $251,402.0$ \\
\hline
\end{tabular}

Notes:

Figures in parentheses are negative numbers.

*End-of-year balance $=$ tax revenue + intergovernmental transfer + previous year revenue - total expenditures.

Source:

$\mathrm{X} 1$ township finance bureau.

discernable that X2's fiscal revenue shrank with the phasing in of the tax-for-fees reform in the late 1990s: the extra-budgetary revenue in Table 6 would have disappeared. This has also been confirmed in interviews with households. Before the tax reform, an average household had to pay the township government 200-400 yuan of fees and surcharges every year, including education surcharges, and fees to build bridges and roads.

On the other hand, the collapse of township enterprises had a bad effect on the township's fiscal situation. Profits from collective enterprises, which accounted for the bulk of self-raised funds, contributed 65 per cent of total income in 1995, as shown in Table 6. This largely vanished with the collapse of numerous enterprises. It is no wonder that the basic survival of X2 township authority is now largely reliant upon intergovernmental transfers.

Looking at this evidence from another angle, since profits from collective enterprises used to constitute the bulk of the township authority's income, the government's fiscal expenditures must have been largely funded by the enterprises. This evidence aside, the "public" role of collective enterprises has been confirmed by the township head. The X2 township head confided that: "With the 
Table 5: X2 Township Budgetary Revenue and Expenditures (2003)

\begin{tabular}{|c|c|c|c|}
\hline & Yuan & & Yuan \\
\hline $\begin{array}{l}\text { Total Tax Revenue } \\
\text { of which: }\end{array}$ & $253,737.1$ & $\begin{array}{l}\text { Total Expenditures } \\
\text { of which: }\end{array}$ & $917,189.8$ \\
\hline Business tax $(60.5 \%)$ & $153,399.2$ & $\begin{array}{l}\text { Education expenses } \\
(48.7 \%)\end{array}$ & $446,962.8$ \\
\hline $\begin{array}{l}\text { Enterprise income tax } \\
(21.6 \%)\end{array}$ & $54,872.3$ & $\begin{array}{l}\text { Admin and management } \\
\text { fees }(11.8 \%)\end{array}$ & $108,206.0$ \\
\hline $\begin{array}{l}\text { Agricultural tax } \\
\left(13.2^{\%} \%\right)\end{array}$ & $33,598.7$ & $\begin{array}{l}\text { Healthcare expenses } \\
\qquad(14.7 \%)\end{array}$ & $134,550.6$ \\
\hline $\begin{array}{l}\text { Intergovernmental } \\
\text { transfer }\end{array}$ & $606,676.0$ & & \\
\hline Previous year revenue & $148,459.7$ & End-of-year balance & $91,683.0^{*}$ \\
\hline Budgetary revenue & $260,456.8$ & Budgetary expenditures & $930,629.3$ \\
\hline Extrabudgetary revenue & $260,230.1$ & $\begin{array}{l}\text { Extrabudgetary } \\
\text { expenditures }\end{array}$ & $270,996.6$ \\
\hline
\end{tabular}

Note:

*End-of-year balance $=$ tax revenue + intergovernmental transfer + previous year revenue - total expenditures.

Source:

X2 township finance bureau.

Table 6: Fiscal Income of X2 Township (1995)

\begin{tabular}{lrr}
\hline & \multicolumn{1}{c}{ Yuan } & $\%$ \\
\hline Budgetary funds & 81,081 & 23.4 \\
Extra-budgetary funds & 37,522 & 10.8 \\
Self-raised funds & 228,202 & 65.8 \\
Total income & 346,805 & \\
\hline
\end{tabular}

Source:

$\mathrm{X} 2$ township finance bureau director.

collapse and transformation of the collective enterprises, now we have no money to build or mend roads, or to renovate our primary schools. Apart from contributing their profits to the township's self-raised funds, we always required the enterprises to pay for or subsidize the costs of road and school construction, something that we cannot demand from the private enterprises now."

Township governments' debts and township enterprises. There were 12 township enterprises in $\mathrm{X} 1$ at the peak of their development in the early 1990s. Eight of them have collapsed and the remaining four have been bought over by private individuals; hence there is none left today. X1 used to have an RCF through which most collective 
enterprises in the township financed their activities. When the RCF was closed, an outstanding non-performing loan of 1.88 million yuan was transferred to the RCC branch in X1 township. About 500,000 yuan of this loan (26.6 per cent) was owed by the township enterprises in X1, and none of it had been repaid. ${ }^{47}$ The township enterprises also owed 90,000 yuan of loans directly to the X1 RCC branch, all of which had become non-performing. These loan transactions took place between the late 1980s and early 1990s. ${ }^{48}$ The two figures combined give a total of 590,000 yuan owed by X1 township government to the local RCC branch. As shown in Table 4, based on annual tax revenue of 400,000 yuan and annual fiscal deficits of 100,000 yuan, X1 will need two full years of revenue generation without any incurring any expenditure to pay off the debt to the RCC!

On the other hand, X2 oversaw the development of township enterprises on a greater scale during the late 1980s and early 1990s. Due to its natural resource endowments, the township attracted enterprises in the areas of mineral extraction and processing, and hydroelectricity. Of the 15 township enterprises in the early 1990 s, five have been rented to private individuals and the remaining ten have collapsed. There was no RCF in X2: financing of township enterprises was from the local RCC and ABC branch. Township enterprises collectively owed X2 RCC a total of 2.96 million yuan in principal, not including interest. The transactions took place some ten years ago and have all become bad debt. ${ }^{49}$ The RCC aside, the township government had also sought financial support from the ABC for larger-scale projects. There were two projects where the township government, in the names of township enterprises, borrowed four million yuan each from the $\mathrm{ABC}{ }^{50}$ According to the $\mathrm{ABC}$ manager, the bank considered one million out of the total eight million yuan as non-performing. Combining the debts from the RCC and ABC, X2 township government's debt level came to 11 million yuan. ${ }^{51}$ The township's tax revenue of 250,000 yuan a year is only 2 per cent of its total debt. It is unimaginable how X2 will ever be able to pay off its liabilities to the financial institutions.

The fiscal situations of the townships in $\mathrm{X}$ county are not unique. My field investigations in $\mathrm{Y}$ county suggest that the local governments

47. Personal interview with the $\mathrm{X} 1 \mathrm{RCC}$ manager.

48. Personal interviews with the X1 RCC manager and the X1 township Party secretary.

49. Personal interviews with the RCC manager in X2 township and the general manager of X2 Enterprise Pte Ltd.

50. Personal interviews with the county ABC manager, and the general manager of X2 Enterprise Pte Ltd. To my knowledge, the debt has not been paid off as of July 2004.

51. When I asked the RCC and ABC managers how the township government could borrow from the financial institutions when the law specifically prohibited that, the interviewees said that most of the loans were given before the law came into force; and even if the law was in place, most of the dealings between grassroots governments and grassroots financial organizations was generally beyond the knowledge of the higher authorities. 
there are in just as dire straits. Appendix 1 shows the tax revenue and debt levels of the townships in $Y^{52}$ According to the county official statistics, the average debt-to-revenue ratio was three, and as high as six to seven in some townships. Worse yet, my investigations in two townships suggest that the actual debt levels were higher than the official records. In Y1, the total debt was six million yuan, rather than 3.2 million as the official statistics indicate. ${ }^{53}$ Several officials in Y2 conceded that there were widespread wage arrears in the years before the guarantee of salaries by the county government in 2004. It was commonplace for township officials to receive only nine months' pay in a year. ${ }^{54}$

High debt-to-revenue ratio is less of a concern if the intergovernmental transfers are able to compensate the townships for revenue shortfalls. However, as discussed above, the under-funding and lack of transparency of the system often produce outcomes that are unfavourable for grassroots governments. More importantly, in poor local areas, such as the localities of the case studies, the financial survival of the counties and prefectures is often problematic and they have to rely heavily on transfers from the province, leaving them in a weak position to assist the townships. ${ }^{55}$ Several township finance bureau directors told me that transfers promised by the county and prefecture governments had simply failed to come through, and if they did, the transfer amounts were less than promised. ${ }^{56}$

Table 7 summarizes township enterprise debts, fiscal revenue and debt-to-fiscal revenue multiples of the four townships. Township enterprise debt as a multiple of fiscal revenue ranged from 1.4 and 7.3 times in $\mathrm{X} 1$ and $\mathrm{Y} 1$ respectively, to 42.2 and 35.6 times in $\mathrm{X} 2$ and $\mathrm{Y} 2$ respectively. The sheer magnitude of the debt-to-revenue multiples is staggering and extremely worrying.

Why does the size of debt due to township enterprise financing differ so much among the cases? Data available from this study suggest that debt size is positively related with the number and scale of township enterprises hosted by a township. Since enterprise financing comes almost entirely from financial institutions, one township will accumulate more debt if it hosts more and larger-scale enterprises

52. Similar data are however unavailable for X county.

53. Personal interview with the Y1 township head.

54. Personal interview with Y2 township officials.

55. My fieldwork investigations suggest that many prefectural and county governments are burdened with heavy debt; and the causes are more varied than those of the township authorities, including bloated government payrolls, losses incurred by the state grain marketing companies, arrears of social welfare payments and debts of state-owned enterprises.

56. The shortfalls in intergovernmental transfers are an escalating problem: a $\mathrm{X}$ county finance bureau director complained to me that the county had limited capacity to assist the townships because the county was in a bad shape financially, and many transfers and financial assistance promised by the prefecture never came through. The director then went on to explain that the prefecture government itself was also in financial difficulties, and had to rely heavily on transfers from higher authorities to survive. 
than another, if other factors such as performance of enterprises and township's fiscal balance, among other things, are equal. Accordingly, the multiple of debt and fiscal revenue is the highest in X2 township for two reasons. First, it used to host more and larger-scale township enterprises than the others. Secondly, since the collapse of the enterprises, X2 township has not found alternative revenue sources to fill the vacuum left by collective enterprises' contribution. This is apparent from a comparison between its fiscal revenue in 1995 and 2003 (Tables 5 and 6). The township's total revenue fell by an absolute amount of 93,068 yuan after seven years or an equivalent of 26.8 per cent. ${ }^{57}$ If $\mathrm{X} 2$ has developed the number of individual commercial establishments that $\mathrm{X} 1$ has, it would be collecting more business tax like X1 (see Table 4). ${ }^{58}$

\section{Conclusions}

Township governments were able to mobilize resources from local financial organizations because these organizations had weak corporate governance that failed to represent the interests of member households, created no checks-and-balances on the power of the $\mathrm{RCC} / \mathrm{RCF}$ manager and allowed the township authorities to interfere in the loan allocation process. Worse yet, the board of directors of the RCFs was headed by the township head or someone appointed by the township authority, which allowed the township government to have direct control over resource allocations.

Loans to township enterprises were mostly provided with guarantees from the township authorities without any physical collateral. In cases where collaterals were present, township assets were often grossly overvalued. Compared to the state-owned banks, the local financial organizations were under greater pressure to give in to the demand to support local government-initiated projects because they were independent legal entities that were accountable to no one. The local authorities had also established the RCFs, which were local informal financial organizations that lacked accountability and made it easy for the authorities to tap into their resources.

As shown in Table 7, when the RCFs were shut down, their portfolios, including savings and loans, were transferred to the RCCs. Hence, much of the township governments' debts borrowed from the RCFs are now owed to the RCCs. The debt levels of Y2 and X2 township governments are as high as 36 and 42 times respectively those of their fiscal revenue. It is simply unimaginable how these

57. These are nominal numbers without taking inflation into account.

58. Of course, X1 township has the advantage of being a county seat, and this has helped to boost its service sector that pays business tax (yingye shui). Further, it is notable that business tax is a local tax (difang shui) as $80 \%$ of the revenue goes to township government and the remaining $20 \%$ goes to a higher level, compared to enterprise income tax that is shared between township and higher governments with a ratio of $4: 6$. 
Table 7: Key Figures of the Four Townships' Fiscal Debt and Revenue

\begin{tabular}{|c|c|c|c|c|}
\hline & $X 1$ & $X 2$ & $Y 1$ & $Y 2$ \\
\hline $\begin{array}{l}\text { Debt due to } \\
\text { township } \\
\text { enterprise } \\
\text { financing } \\
\text { (2003) }\end{array}$ & $\begin{array}{l}590,000 \text { yuan } \\
\text { owed to } \\
\text { RCC; of } \\
\text { which: } 90,000 \\
\text { yuan to RCC, } \\
\text { and } 500,000 \\
\text { yuan to RCF } \\
\text { later } \\
\text { transferred } \\
\text { to RCC }\end{array}$ & $\begin{array}{l}11 \text { million } \\
\text { yuan owed } \\
\text { to } \mathrm{ABC} \text { and } \\
0 \text { RCC; of } \\
\text { which: } 2.96 \\
\text { million yuan } \\
\text { to } \mathrm{RCC} \text {, and } \\
8 \text { million } \\
\text { yuan to } \mathrm{ABC}\end{array}$ & $\begin{array}{l}6 \text { million } \\
\text { yuan } \\
\text { (personal } \\
\text { interview); } \\
3.28 \text { million } \\
\text { yuan } \\
\text { (official } \\
\text { statistics); } \\
\text { of which: } \\
1.38 \text { million } \\
\text { RCFs' } \\
\text { liabilities }\end{array}$ & $\begin{array}{l}12.1 \text { million } \\
\text { yuan (official } \\
\text { statistics); of } \\
\text { which: } 1 \\
\text { million yuan } \\
\text { to RCC; } 2.7 \\
\text { million yuan } \\
\text { RCFs' } \\
\text { liabilities }\end{array}$ \\
\hline $\begin{array}{l}\text { Fiscal revenue } \\
\quad(2003)\end{array}$ & 416,113 yиап & 260,456 yиап & 820,000 yиап & 340,000 yuan \\
\hline $\begin{array}{l}\text { Fiscal balance } \\
\text { (2003) }\end{array}$ & $\begin{array}{l}\text { 96,298 yuan } \\
\text { (deficits) }\end{array}$ & 91,683 yиап & - & - \\
\hline $\begin{array}{l}\text { Township debt/ } \\
\text { Fiscal revenue }\end{array}$ & 1.4 & 42.2 & 7.3 & 35.6 \\
\hline
\end{tabular}

Sources:

Interviews with various townships' finance bureau directors and township heads.

townships will ever pay off these debts, which are ultimately the savings of rural households.

Local financial organizations had often become a means to supplement the grassroots governments' coffers (xiaojinku 小金库) since the people who managed the financial resources were also the ones who ran the governments. Fundamentally, this reflects the lack of separation between Western notions of "finance" and "public finance." This explains why the financial system in China has always suffered from a lack of independence from the state, especially at the grassroots level.

Local government debt from township enterprise financing has grown to a worrying scale: the debt was as high as 42 times the size of the fiscal revenue in one of the townships. These are the townships that have not been able to find alternative revenue sources to fill the gap left by township enterprises. They are hardly able to function properly if they are to rely on their own meagre fiscal revenue, let alone repay the debt. On a nationwide scale, according to one estimate, the local government debt combined was one trillion yuan, or 8.3 per cent of China's GDP at 2003 prices. However this is likely to underestimate the actual magnitude given the predominance of latent debt. 
Appendix 1: Revenue and Debt of Townships in Y County (2003)

\begin{tabular}{|c|c|c|c|c|c|}
\hline Townships & $\begin{array}{c}G D P \\
(\cdot 000 Y)\end{array}$ & $\begin{array}{c}\text { Per capita } \\
\text { income }(Y)\end{array}$ & $\begin{array}{c}\text { Tax revenue } \\
\text { ('000 Y) }\end{array}$ & $\begin{array}{c}\text { Debt } \\
(\cdot 000 Y)\end{array}$ & $\begin{array}{c}\text { Debtlax } \\
\text { revenue }\end{array}$ \\
\hline $\mathrm{JC}$ & 186,900 & 2,335 & 4,930 & 10,600 & 2.2 \\
\hline $\mathrm{XZ}$ & 97,530 & 2,342 & 3,820 & 5,030 & 1.3 \\
\hline MA & 61,910 & 1,896 & 2,680 & 1,900 & 0.7 \\
\hline YA & 31,000 & 1,625 & 2,540 & 8,160 & 3.2 \\
\hline $\mathrm{ZX}$ & 53,720 & 2,094 & 3,600 & 4,680 & 1.3 \\
\hline $\mathrm{TM}$ & 64,530 & 1,955 & 5,680 & 17,100 & 3.0 \\
\hline FX & 73,860 & 1,901 & 3,060 & 6,940 & 2.3 \\
\hline GZ & 33,290 & 1,942 & 2,040 & 2,700 & 1.3 \\
\hline $\mathrm{XF}$ & 25,770 & 1,930 & 1,570 & 11,110 & 7.1 \\
\hline SJ & 27,920 & 2,000 & 1,660 & 5,860 & 3.5 \\
\hline $\mathrm{HC}$ & 29,590 & 1,916 & 2,780 & 11,910 & 4.3 \\
\hline LY & 35,070 & 1,935 & 2,880 & 3,300 & 1.1 \\
\hline YL & 18,510 & 1,767 & 1,800 & 11,790 & 6.6 \\
\hline LS & 26,420 & 1,880 & 1,810 & 6,180 & 3.4 \\
\hline $\mathrm{SH}$ & 38,360 & 2,048 & 2,630 & 9,640 & 3.7 \\
\hline WZ & 19,540 & 1,811 & 1,900 & 5,790 & 3.0 \\
\hline $\mathrm{DZ}$ & 32,150 & 1,900 & 2,520 & 8,800 & 3.5 \\
\hline ED & 59,210 & 1,801 & 2,420 & 4,020 & 1.7 \\
\hline $\mathrm{XJ}$ & 26,460 & 1,826 & 2,360 & 8,790 & 3.7 \\
\hline $\mathrm{JZC}$ & 13,250 & 1,820 & 1,260 & 5,510 & 4.4 \\
\hline DY & 32,430 & 1,930 & 2,100 & 5,540 & 2.6 \\
\hline Y1 & $\mathbf{2 8 , 8 8 0}$ & 1,886 & 2,050 & 12,100 & 5.9 \\
\hline WF & 36,510 & 2,140 & 1,530 & 3,450 & 2.3 \\
\hline Y2 & 21,780 & 1,820 & 1,860 & 3,280 & 1.8 \\
\hline YC & 24,780 & 1,813 & 3,050 & 3,010 & 1.0 \\
\hline $\mathrm{BP}$ & 22,810 & 1,645 & 1,740 & 7,600 & 4.4 \\
\hline WX & 24,120 & 1,663 & 2,840 & 5,300 & 1.9 \\
\hline SS & 19,710 & 1,757 & 1,670 & 5,450 & 3.3 \\
\hline LM & 17,610 & 1,718 & 1,210 & 1,820 & 1.5 \\
\hline MY & 19,730 & 1,920 & 1,660 & 8,890 & 5.4 \\
\hline $\mathrm{TG}$ & 28,890 & 1,819 & 2,150 & 4,080 & 1.9 \\
\hline LS & 12,510 & 1,986 & 1,110 & 5,710 & 5.1 \\
\hline GM & 31,690 & 2,064 & 2,400 & 7,270 & 3.0 \\
\hline $\mathrm{ZB}$ & 26,610 & 2,060 & 1,820 & 2,800 & 1.5 \\
\hline $\mathrm{SP}$ & 19,750 & 2,010 & 1,490 & 4,110 & 2.8 \\
\hline FY & 17,800 & 1,710 & 1,700 & 4,000 & 2.4 \\
\hline SQ & 22,350 & 1,830 & 1,670 & 2,380 & 1.4 \\
\hline DF & 25,140 & 1,713 & 1,710 & 3,110 & 1.8 \\
\hline FL & 17,190 & 1,803 & 1,700 & 5,020 & 3.0 \\
\hline ML & 15,290 & 1,819 & 1,430 & 4,700 & 3.3 \\
\hline LY & 20,610 & 1,857 & 1,700 & 4,510 & 2.7 \\
\hline $\mathrm{BC}$ & 17,110 & 1,840 & 1,450 & 1,390 & 1.0 \\
\hline LX & 18,530 & 1,820 & 1,480 & 2,500 & 1.7 \\
\hline $\mathrm{TS}$ & 19,480 & 1,812 & 1,660 & 3,510 & 2.1 \\
\hline $\mathrm{SF}$ & 20,300 & 1,757 & 1,600 & 5,310 & 3.3 \\
\hline XD & 13,120 & 1,730 & 1,520 & 5,800 & 3.8 \\
\hline QY & 13,800 & 1,783 & 1,300 & 3,930 & 3.0 \\
\hline
\end{tabular}


Appendix 1 (Continued)

\begin{tabular}{lccccc}
\hline Townships & $\begin{array}{c}\text { GDP } \\
(' 000 Y)\end{array}$ & $\begin{array}{c}\text { Per capita } \\
\text { income }(Y)\end{array}$ & $\begin{array}{c}\text { Tax revenue } \\
(\text { '000 } Y)\end{array}$ & $\begin{array}{c}\text { Debt } \\
(' 000 Y)\end{array}$ & $\begin{array}{c}\text { Debt/tax } \\
\text { revenue }\end{array}$ \\
\hline DL & 13,610 & 1,720 & 1,380 & 3,500 & $\mathbf{2 . 5}$ \\
YM & 18,140 & 1,802 & 1,650 & 6,230 & $\mathbf{3 . 8}$ \\
HZ & 11,610 & 1,739 & 1,240 & 1,950 & $\mathbf{1 . 6}$ \\
YT & 14,320 & 1,654 & 1,300 & 4,860 & $\mathbf{3 . 7}$ \\
CF & 15,460 & 1,880 & 1,010 & 2,940 & $\mathbf{2 . 9}$ \\
LY & 13,730 & 1,665 & 1,240 & 3,210 & $\mathbf{2 . 6}$ \\
LQ & 18,600 & 1,737 & 1,500 & 5,280 & $\mathbf{3 . 5}$ \\
NQ & 19,440 & 1,600 & 1,500 & 5,880 & $\mathbf{3 . 9}$ \\
YG & 13,820 & 1,720 & 1,250 & 5,050 & $\mathbf{4 . 0}$ \\
JG & 14,880 & 1,726 & 1,380 & 5,640 & $\mathbf{4 . 1}$ \\
JL & 18,330 & 1,800 & 1,640 & 7,550 & $\mathbf{4 . 6}$ \\
BJ & 16,130 & 1,673 & 1,500 & 7,670 & $\mathbf{5 . 1}$ \\
DT & 16,460 & 1,838 & 1,690 & 3,600 & $\mathbf{2 . 1}$ \\
WP & 14,570 & 1,612 & 1,610 & 3,400 & $\mathbf{2 . 1}$ \\
AL & 11,260 & 1,679 & 1,460 & 1,710 & $\mathbf{1 . 2}$ \\
MP & 12,180 & 1,631 & 1,240 & 3,460 & $\mathbf{2 . 8}$ \\
BY & 14,610 & 1,827 & 1,390 & 2,590 & $\mathbf{1 . 9}$ \\
XC & 14,060 & 1,747 & 1,160 & 3,520 & $\mathbf{3 . 0}$ \\
ZS & 18,560 & 1,790 & 1,170 & 7,100 & $\mathbf{6 . 1}$ \\
YS & 29,130 & 2,048 & 2,250 & 3,700 & $\mathbf{1 . 6}$ \\
GS & 26,850 & 2,073 & 1,750 & 1,170 & $\mathbf{0 . 7}$ \\
HS & 25,660 & 2,040 & 2,130 & 3,460 & $\mathbf{1 . 6}$ \\
Average & $\mathbf{2 7 , 7 5 3}$ & $\mathbf{1 , 8 4 7}$ & $\mathbf{1 , 9 4 2}$ & $\mathbf{5 , 3 6 0}$ & $\mathbf{3}$ \\
& & & & & \\
\hline & & & & &
\end{tabular}

